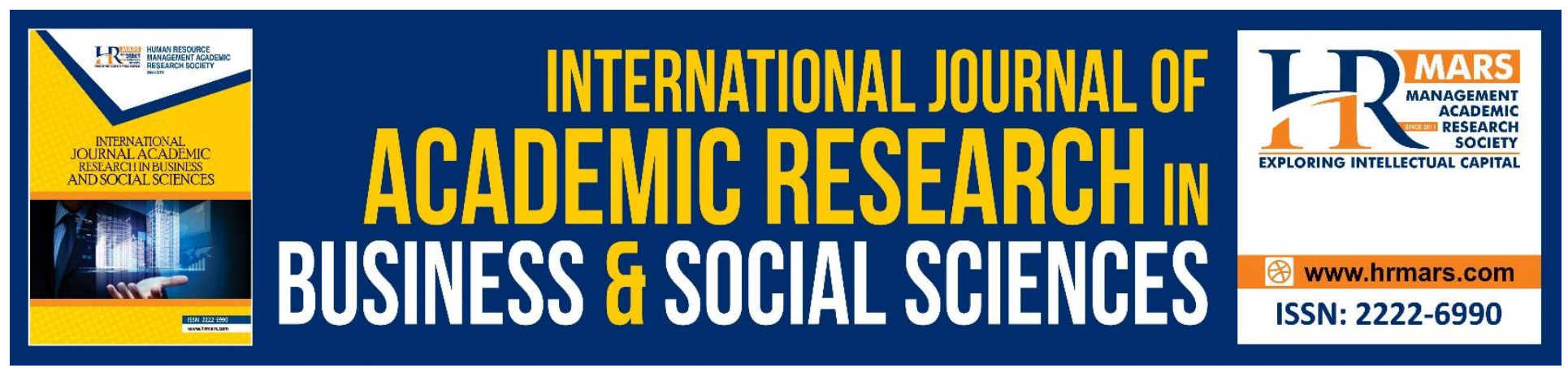

\title{
Sustainability of Zakah Distribution in Baitul Mal Aceh: Basic and Implementation Methods
}

Nurul llyana Muhd Adnan, Mohd Izhar Ariff Mohd Kashim, Ahmad Dahlan Salleh, Ezad Azraai Jamsari, Md Yazid Ahmad \& Noor Izzati Ab Rahman

To Link this Article: http://dx.doi.org/10.6007/IJARBSS/v9-i1/5457

DOI: $\quad 10.6007 /$ IJARBSS/v9-i1/5457

Received: 05 Jan 2019, Revised: 25 Jan 2019, Accepted: 30 Jan 2019

Published Online: 13 Feb 2019

In-Text Citation: (Adnan et al., 2019)

To Cite this Article: Adnan, N. I. M., Kashim, M. I. A. M., Salleh, A. D., Jamsari, E. A., Ahmad, M. Y., \& Rahman, N. I. A. (2019). Sustainability of Zakah Distribution in Baitul Mal Aceh: Basic and Implementation Methods. International Journal of Academic Research in Business and Social Sciences, 9(1), 554-562.

\section{Copyright: (C) 2019 The Author(s)}

Published by Human Resource Management Academic Research Society (www.hrmars.com)

This article is published under the Creative Commons Attribution (CC BY 4.0) license. Anyone may reproduce, distribute, translate and create derivative works of this article (for both commercial and non-commercial purposes), subject to full attribution to the original publication and authors. The full terms of this license may be seen at: http://creativecommons.org/licences/by/4.0/legalcode

Vol. 9, No. 1, 2019, Pg. 554 - 562

Full Terms \& Conditions of access and use can be found at http://hrmars.com/index.php/pages/detail/publication-ethics 


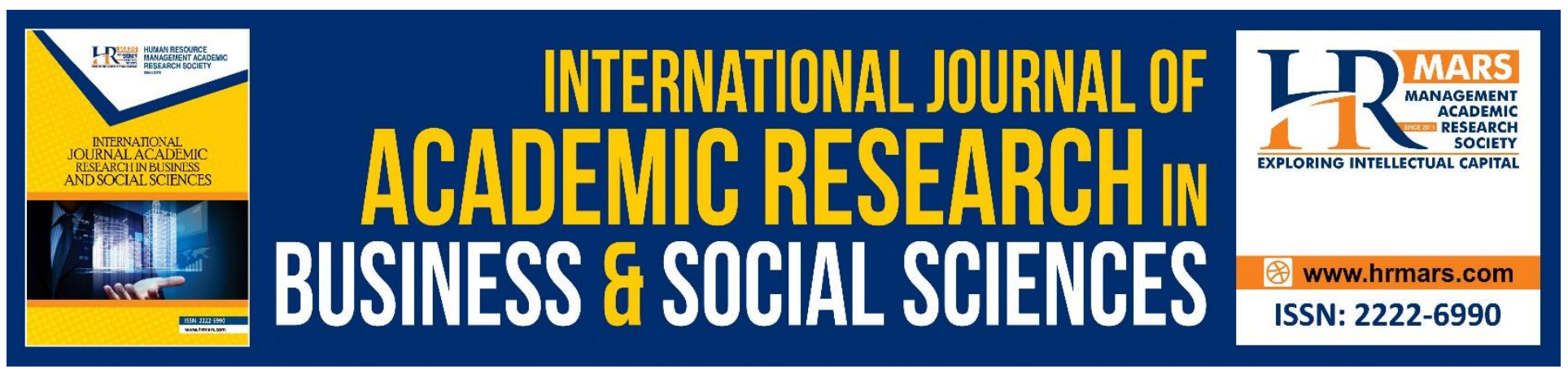

\title{
Sustainability of Zakah Distribution in Baitul Mal Aceh: Basic and Implementation Methods
}

\author{
${ }^{1}$ Nurul llyana Muhd Adnan, ${ }^{1}$ Mohd Izhar Ariff Mohd Kashim, ${ }^{1}$ Ahmad \\ Dahlan Salleh, ${ }^{2}$ Ezad Azraai Jamsari*, ${ }^{1}$ Md Yazid Ahmad \& ${ }^{3}$ Noor \\ Izzati Ab Rahman \\ ${ }^{1}$ Centre for Contemporary Fiqh and Sharia Compliance, Faculty of Islamic Studies, \\ Universiti Kebangsaan Malaysia, 43600 UKM Bangi, Selangor, Malaysia \\ ${ }^{2}$ Centre for The Middle East and Nusantara, Faculty of Islamic Studies, \\ Universiti Kebangsaan Malaysia, 43600 UKM Bangi, Selangor, Malaysia \\ ${ }^{3}$ School of Accounting, Finance and Quantitative Studies, \\ Asia Pacific University of Technology \& Innovation, 57000 Kuala Lumpur, Malaysia \\ *Corresponding Author: eajsti@gmail.com
}

\begin{abstract}
Currently, the working capital for micro businesses is provided by free from the zakah institution in Malaysia. However lately, the amount of zakah distribution by zakah institutions in Malaysia has exceeded the accumulated amount. For long-term planning, among the proposed alternative approach is through the distribution of working capital in the form of micro financing. The question is, what is the substructure and method of implementation? Based on content analysis, the distribution of working capital by microfinance are justified and agreed upon by scholars of zakah. In fact, Baitul Mal Aceh successfully exhibit in the distribution of zakah funds through microfinance. The findings showed that Baitul Mal Aceh regarding the amount of loans had increased by Rp 500000 on average and the returns were more than $75 \%$. The implication of the distribution of zakah funds through micro financing shows the presence of sustainability in the distribution of zakah funds. In addition, it not just could create a revolving fund, but the distribution of zakah can be done continuously although the amount of zakah collection may be impaired.
\end{abstract}

Keywords: Sustainability, zakah distribution, Baitul Mal Aceh, basic and implementation methods

\section{INTRODUCTION}

Most small entrepreneurs in Malaysia need a start-up capital to start their business. Many of them also need additional capital to upgrade existing businesses. Among the capital assistance available to small entrepreneurs is from banking and other sources, such as Islamic pawnshops and lent from their relatives. Among the most popular are lending through micro-credit schemes. However, micro- 
credit transactions are deemed to be free from usury. Therefore, a mechanism for microcredit that is free from usury needs to be realized. According to economic perspective, zakah plays an important role in ensuring that every member of society can fulfill their basic needs. It can ensure stability in the economic environment as well as generate demand especially from the lower income group. With this mechanism, the economy will be more stable because the poor will always be taken care, while the rich will contribute and concern to the poor.

This will directly or indirectly create economic and social stability because no one will feel oppressed. Thus, the discussion in this article is divided into three parts. The first part will discuss the basic distribution of zakah in the form of micro credit. This is followed by a second section which will discuss the method of implementation in Baitul Mal Aceh. Finally, in the third section will be discussed about the conclusion of the study. Hence, studies relating to the excellence of contemporary issues in Islamic jurisprudence and shariah studies are also assayed by local scholars, covering various issues such as discussion of halal pharmaceuticals (Halim et al. 2015), the establishment of shariah supervisory committee in hospital (Samsudin et al. 2015), the principles of the use of haram sources in food processing (Kashim et al. 2015), the baitulmal's potential as trustee for unclaimed moneys of Muslims (Ahmad et al. 2017), as well as the issue of istihalah and its effects on food from the Islamic perspective (Kashim et al. 2018)

\section{BASIC DISTRIBUTION OF ZAKAH THROUGH CREDIT MICRO}

Baitul Mal Aceh is an institution in the Islamic state that has distributed zakah through microfinance. In Aceh, Law No. 11/2006 has confirmed zakah, wakaf property and religious property organized by Baitul Mal Aceh and Baitul Mal Regency or City. Qanun Aceh No. 10/2007 is about the establishment of Baitul Mal Aceh, Baitul Mal Regency or Municipal Baitul Mal for District and Village Baitul Mal. The effort towards empowering zakah funds productively was stated in Qanun Aceh No. 10/2007. Qanun Aceh No. 10/2007, clause 29 mentioned that the recipients of zakah in productive form must meet three conditions. The first is, they should already have a decent productive effort. The second is willing to accept a co-worker who serves as a mentor. The third is willing to submit business reports on a regular basis every six months.

The Zakah distribution techniques through microcredit are part of a muamalah issue. It belongs to the muamalah group where hukm (the law) is no detailed text (Armiadi 2009; Rosele et al, 2018). For this purpose, the Islamic Sharia only provides basic rules, general criteria and principles that are in line with the objective of syarak which benefits and does not harm the human race. The original law of muamalah is ibahah (must) as long as there is no argument that prohibits it. Hence, in principle various muamalah activities include micro credits from zakah funds is allowed as long as no argument prohibits them. But it should not be deviated from Maqasid al-Shari'ah who takes care of the benefits of humanity.

Al-Qaradawi (1994) says, zakah distribution techniques are under the jurisdiction of the government. But then, what is stated by al-Qaradawi is based on the duty of the government that is bound to take care of maslahah of the people. This is based on the method of tasarruf al-imam 'ala al-ra'iyyah 
according to bi al-maslahah. Even though zakah must be distributed immediately, however, if there is a maslahah (benefit ) that is required to be delayed the distribution, the government is entitled to do so. Al-Ru'ayni (1995) mentions: "The government may delay the distribution of zakah to the second year if the ijtihad shows the action".

Based on the above argument, the Government needs a certainty and confident to apply for zakah distribution technique because it is closely related to social change. This is closely related to 'urf and community benefits at certain times and places. Therefore, maslahah 'ammah (public interest) is different according to the difference of society. This is in line with the universal nature of the Islamic Sharia itself. The basis used by the scholars' in determining this mechanism is Maqasid al-Shari'ah (Kashim et al. 2018). Since the micro credit through this zakah fund benefits the local community, it can be implemented. Furthermore, no script (primary and secondary source) prohibits it.

The distribution of zakah through micro credit does not contradicted with the concept of maslahah 'ammah to be achieved. Zakah given through micro credit to a mustahiq in a certain amount is to provide an opportunity for a greater effort to work with sufficient capital. This is to liberate himself from poverty and finally the mustahiq through microfinance become muzakki in the future. This also will not harm the maslahah of the other mustahiq. The capital fund from micro credit that has been granted will be restored by mustahiq to zakah institution to be redistributed to other mustahiq. Through this micro credit, Muslims will not be involved by the business consisting the usury and finally the objective of zakah that eradicate poverty will be achieved. This is in line with the Maqasid alShari'ah base which attracts goodness and rejects harm. This related to the meaning of sharia for keeping religion, soul and glory successfully achived (Kashim et al. 2018). It is more beneficial than distributing zakah in the form of consumerism to mustahiq which result in their dependence on the next zakah distribution, which is the mustahiq will never get out of the poverty gap.

Armiadi (2009) argues that the distribution of zakah in the form of working capital through microcredit is categorized in tahsiniyyah level which is the lowest level after hajiyyah and daruriyyah. Every effort to fulfill the need of tahsiniyyah raises the law of sunat (supplementary), while ignoring the need of tahsiniyyah raises the law of makruh. Therefore, micro credit can be done even though zakah collection has not been able to meet the basic needs of all societies. This is not contrary to the origin of zakah which is daruriyyah. The working capital through the micro-credit that become tahsiniyyah is implemented once the subsistence is perfected. Eligible mustahiq must meet the criteria set and accompanied by the monitoring of the responsible party. This is to ensure the fund will be reimbursed later.

The effectiveness of this microcredit will be proven when the productive zakah grant is done continuously (Zahri 2010). The maslahah which is daruriyyah in the recipient of zakah will be solved slowly but it will certainly to be end. Each recipient of zakah who has received productive zakah will strive to become independent until they will no longer depend on zakah. When they are able to be independent, therefore they are free from poverty. This means that the meaning of sharia like keeping the religion, soul and glory is achieved successfully. Consequently, this micro credit is 
certainly more beneficial than the distribution of zakah in the form of self-subsistence which results in their dependence on the distribution of zakah. Zakah recipients are unlikely to be free from poverty.

Al-Qaradawi (2002) permits the use of zakah as a debt. He points out the views of Abu Zahrah, 'Abd al-Wahhab Khallaf and 'Abd al-Rahman ibn Hasan. According to them, it is allowed to give a debt to the needy groups of al-Gharimin and it should be done systematically by creating special funds. The arguments he raised were:

1. Achieving the general maqasid because practically, zakah can contribute in combating the usury system and conventional bank system.

2. Qiyas al-Awla against the payment of zakah to pay the debt. If zakah can be used to pay the debt, therefore the use of zakah in al-qard al-hasan that is free to return to bayt al-mal is more important.

In addition to the arguments presented, it also may argue with qiyas to the orphan's property. Some scholars of the Shafi'i sect allow it. Even scholars in certain circumstances said that giving debt is more preferable if they can keep them from being destroyed. Al-Nawawi (n.d.) said: "It is not necessary for a qadi to keep it (wadi'ah) if he is able to give it in the form of debt".

This is because debtors are responsible for the debt in the form of loans. In this situation, the maslahah is the reason for giving debt because it is more beneficial to orphans. Similarly, in the case of zakah. Governments and zakah workers should make maslahah asnaf a priority. In fact, many of the original things are not allowed on zakah but it is permissible if it provides benefits to zakah and asnaf. For example, the fuqaha allows the government or institution that manage zakah to sell zakah in animals if it is feared to perish or face high threats or costs of care (Ibn Qudamah n.d.; al-Nawawi n.d.).

However, it must be thru after fulfilling some requirements to achieve the maslahah being targeted. The Maslahah need to be addressed not only to the debtors, but the maslahah to the other asnaf should also be kept so that they are not excluded for it. In order to apply for credit from zakah money, there are certain things, including:

1. It must be guaranteed the debt can be paid. Therefore scholars who allow qadi to give debt from the orphan's property require debt to be given to the trustee and not poor (al-yasar). However, this can be accommodated by requiring collateral (kafalah) to the debt provided.

2. The giving of qard (loan) of zakah must not cause the asnaf to be banned from receiving their rights. Therefore, it is not possible unless the accumulated zakah can be properly distributed to the asnaf carefully.

3. The government should seek other alternatives to help small entrepreneurs develop their business and not make zakah as a target to solve the problems faced, especially when there are many asnaf who need it. 
The argument above shows the contemporary scholars' view of the maqasid of the zakah itself. In accordance with what Ibn Qayyim al-Jawziyyah (1975) mentions is the changing and the differentiating fatwas according to the change of place, time, condition of society, intention and customs. They argue that the distribution of zakah in the form of al-qard al-hasan, mudarabah and murabahah contract is justified (al-Qaradawi 2002).

\section{IMPLEMENTATION METHOD FOR ZAKAH DISTRIBUTION IN FORM OF CREDIT MICRO}

The Baitul Mal Aceh, essentially distributing the zakah to all eight asnaf. It includes asnaffaqir, miskin, amil, riqab, mu'allaf, gharimin, fi sabil Allah and ibn sabil. However, asnaf riqab is not intended as there is no asnaf riqab in Aceh at this time. The amount allocated is according to the suitability of the percentage of zakah distribution for all the asnaf. Distribution depends on the number of each asnaf and the amount of zakah requirement. However, the main beneficiary is the fakir and miskin. Giving in the form of self-care is preferred to asnaf fakir. For miskin asnaf, priority is given in term of productive form. Distribution that can generate income from asnaf is through the productive zakah given (Zuriyati \& Nurul Ilyana 2018). For example, business capital fund to asnaf that is involved in trade sector, motorbike sector and agricultural sector.

For that reason, the Shariah Board (Syariah Board Circular No. 01/SE/V/2006) sets the distribution ratio for the fakir by 15 percent, miskin by 30 percent, amil by 10 percent, mu'allaf by 2.5 percent, gharimin by 10 percent, fi sabil Allah as much as 12.5 percent and ibn sabil as much as 20 percent. The resolution of this percentage can be suited to the needs and capabilities of Baitul Mal at the District and City and Village or Kelurahan levels. Zakah funds are not necessarily fully distributed. The balance of zakah funds must be handed over to Baitul Mal Aceh for distribution to other areas. This is after the needs of each asnaf have been fulfilled (Zahri 2012).

The purpose of this business capital is given so that the economic condition of the poor can be developed and not relied solely on aid. In addition, the mustahiq will turn into muzakki one day. AlNawawi (1996) has discussed this. Even the Prophet Muhammad SAW also used this distribution. He gave zakah of two dirhams to a poor man. One dirham for daily expenses and one dirham to buy an axe. The purpose is that the poor man will no longer depend on others because he already has an axe to work (Salam 2007).

The Baitul Mal Aceh distributed micro-credit business capital assistance in two forms. First in the form of cash capital and second in the form of equipment. Capital in cash is given to mustahiq to purchase inadequate business properties. Capital in the form of equipment is provided for equipment that cost a lot (Armiadi 2009). Rizki Aulia, the head of Distribution and Reform Division of Aceh Baitul Mal stated: "The cash capital aid is given to vegetable traders, cakes, clothing, stalls and rattan wigs such as basket. While the capital in the form of equipment is like seed, nursery, fertilizer, motorized trishaw and sewing equipment and making cakes equipment". 
Based on the above statement, it is understood that Baitul Mal Aceh provides capital in cash and in the form of equipment. These two forms of capital are given to traders and farmers who run a small business. For example, cash capital is given to vegetables, food and handicrafts business. Then in form of equipment such as seed, nursery, steel, motor tricycle, sewing equipment and cakes. Baitul Mal Aceh through Lembaga Kewangan Mikro Syariah (or LKMS) has channeled the funds amounting

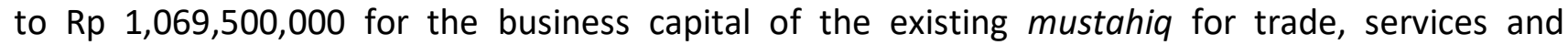
agriculture. The amount of micro-credit business capital assistance from zakah funds distributed monthly is different. It depends on the amount of capital required and the type of economic activity carried out in line with the conditions determined by Baitul Mal Aceh. The maximum amount of capital channeled is Rp 10 million and at least Rp 1 million.

This business capital is given in two forms, the venture capital for joint venture, and else is individually. Productive zakah through the venture capital financing program is one of the main programs of Baitul Mal Aceh that has been running since 2006. This program can raise the poor from the economic shackles that are average below the poverty line. They are expected to become muzakki and no longer mustahiq (Armiadi 2013).

There are two methods of channeling zakah productive in the form of micro credit in Baitul Mal Aceh. First, it is revolving and does not rotate. Rotating capital is channeled in the form of al-qard al-hasan. Meanwhile, for non-revolving capital, it is channeled in the form of capital in cash, goods and so on. For successful applicants, a dedicated Baitul Mal officer will monitor on every activity undertaken by the asnaf entrepreneur to ensure that the efforts are in good working order. During this monitoring period, asnaf entrepreneurs will be given the guidance and training and motivation by the special officer starting from receiving business capital assistance until they succeed in developing their respective companies.

The business capital given must be reimbursed. Therefore, asnaf entrepreneurs must pay installments according to their respective sectors for each given microcredit. The trade and services sectors need to pay by monthly installments, while the agricultural sector will need to be paid according to the acceptance of revenue for the sector. The accepted installment will be used for supporting other new mustahiq. Most of micro-credit receivers in the trade sector consisted of vegetable traders, cakes trader, garments trader, handicraft trader and stalls. Those who are involved with this sector had shown their prestigious success. For example, the previous micro-credit receiver was a small vegetable seller. They have transformed into vegetable wholesalers to vegetables sellers that are just starting their business. Credit micro for this trade sector uses al-qard al-hasan agreement, in example, lending without any additional payment. Monthly installments must be made in accordance with the loan amount received for a year (Zahri 2010).

Initially, the livestock sector was also given acapital assistance. However, in 2008, the livestock sector was terminated and replaced with the service sector. The breeding sector was terminated because it did not bring much profit revenue. Financing for motorized trishaw services was initiated to ease the burden of asnaf entrepreneurs. The micro credit for the trishaw service sector uses the al-qard al- 
hasan contract. This service sector shown a success as finally entrepreneurs can enjoy their income as well as to have their own motorized trishaw. Previously, most of the trishaw used by asnaf entrepreneurs were the rented trishaw (Armiadi 2009). Microcredit for agricultural sector is provided to poor farmers in selected areas. Financing in the agriculture sector also uses al-qard al-hasan. Participants in the agricultural sector are allocated with zakah in the form of subsistence while waiting for their crops to be harvested. When the crops are harvested, for example 40 days for spinach or 90 days for peanut plants, the business capital installment should be fully paid back. For those who did not afford to pay in full, the installments are made in line with their ability. With these micro loans, farmers have been able to expand their agricultural areas so that their income and living standards are better than before.

\section{CONCLUSION}

The microfinance practiced by Baitul Mal Aceh is in line with Qanun Aceh No. 10/2007, clause 29, the distribution of zakah in productive form. Productive zakah distribution through microfinance is still within the permissible range of Islamic law. Similarly, with 'aqad al-qard al-hasan and 'aqad mudarabah, it is still concerned with the permissible matters of ijtihadi. An increase in the loan amount of $\mathrm{Rp} 500,000$ on average as a favorable return exceeds $75 \%$ proving that microfinance is a method that can convert from the recipients of zakah to zakah payers. Therefore, zakah institutions in Muslim countries, especially Malaysia, Brunei and Singapore should consider them to be implemented in their respective countries. In addition, the zakah distribution through the microfinance is one of the methods of distribution to realize the sustainable of zakah.

\section{ACKNOWLEDGMENT}

This study is financed by the research grant of Geran Universiti Penyelidikan (GUP-2018-0073), Universiti Kebangsaan Malaysia.

\section{REFERENCES}

Ahmad, M.Y., Mohamed, N.H., Jamsari, E.A., Zakaria, Z., Omar, A.F. \& Taib, M.S.M. (2017). Baitulmal's potential as trustee for unclaimed moneys of Muslims. International Journal of Civil Engineering and Technology, 8(12), 593-599.

Al-Nawawi, Muhyi al-Din Abu Zakariyya Yahya ibn Sharf. (1996). al-Majmu'Sharh al-Muhadhdhab li al-Shirazi. Cairo: al-Matba'ah al-Muniriyyah.

Al-Nawawi, Muhyi al-Din Abu Zakariyya Yahya ibn Sharf. (n.d.). Rawdat al-Talibin wa 'Umdat alMuftin. Vol. 4. Beirut: Dar al-Kutub al-'llmiyyah.

Al-Qaradawi, Yusuf. (1994). Fiqh al-Zakat: Dirasah Muqaranah li Ahkamiha wa Falsafatiha fi Daw' alQur'an wa al-Sunnah. Cairo: Maktabat Wahbah.

Al-Qaradawi, Yusuf. (2002). Fiqh al-Zakat. Beirut. Mu'assasat al-Risalah.

Al-Ru'ayni, Muhammad ibn Muhammad. (1995). Mawahib al-Jalil fi Sharh Mukhtasar Khalil. Vol. 2. Beirut: Dar Al-Kutub al-'Ilmiyyah.

Armiadi Musa Basyah. (2009). Pentadbiran zakat di Baitul Mal Aceh: Kajian terhadap agihan zakat bagi permodalan masyarakat miskin. Thesis Ph.D. Department of Fiqh and Usul, Academy of Islamic Studies, University of Malaya. 
Halim, M.A.A., Kashim, M.I.A.M., Salleh, M.M.M., Nordin, N. \& Husni, A.M. 2015. Halal pharmaceuticals. The Social Sciences, 10(4): 490-498.

Ibn Qudamah. (n.d.). al-Mughni. Vol. 2. Cairo: Maktabat al-Qahirah.

Kashim, M.I.A.M., Alias, M.N., Zin, D.M.M., Said, N.L.M., Zakaria, Z, Salleh, A.D \& Jamsari, E.A. (2018). Istihalah and its effects on food: An Islamic perspective. International Journal of Civil Engineering and Technology, 9(1), 755-762.

Kashim, M.I.A.M., Jamsari, E.A., Safiai, M.H., Adnan, N.I.M. \& Safri, L.S. (2018). Genetic modified organisms (GMOs) from the perspective of science and maqasid shari'ah. International Journal of Civil Engineering and Technology, 9(8), 1381-1393.

Kashim, M.I.A.M., Majid, L.A., Adnan, A.H.M., Husni, A.M., Nasohah, Z., Samsudin, M.A. \& Yahaya, M.Z. (2015). Principles regarding the use of haram (forbidden) sources in food processing: A critical Islamic analysis. Asian Social Science, 11(22), 17-25.

Law [Undang-undang] No. 11, Year [Tahun] 2006.

Adnan, N. I. M., Kashim, M. I. A. M., Salleh, A. D., Jamsari, E. A., Ahmad, M. Y., \& Rahman, N. I. A. (2019). Sustainability of Zakah Distribution in Baitul Mal Aceh: Basic and Implementation Methods. International Journal of Academic Research in Business and Social Sciences, 9(1), 554-562.

Qanun Aceh No. 10, Year [Tahun] 2007.

Samsudin, M.A., Yahaya, M.Z., Kashim, M.I.A.M., Laluddin, H., Ismail, A.M., Khalid, R.M., Sobri, I.M. \& Sulaiman, S.A.S. (2015). Establishment of shari'ah supervisory committee in hospital: An analysis from perspective of public interest. Asian Social Science, 11(4), 43-47.

Shariah Board Circular [Surat Edaran Dewan Syariah] No. 01/DS/V/2006. 